\title{
Yeni Belgelerin Işı̆̆ında Halifeliğin Kaldırılması ve Hanedan Üyelerinin Yurtdışına Çıkarılmaları
}

\author{
Doç. Dr. Oğuz AYTEPE*
}

\section{ÖZET}

Peygamber Hazreti Muhammed'in ölümü ile ortaya çıkan halifelik, Kureyş Kabilesinden önce Hazreti Ebubekir'e daha sonra Hazreti Ömer,Hazreti Osman ve Hazreti Ali'ye geçmiştir. Daha sonra Emeviler'e ve Abbasiler'e geçen hilafet, 1258'de Moğol hükümdarl Kubilay'ın son halifeyi öldürmesiyle son bulur. Dünyanın birçok yerinde görülen halifelik, Yavuz Selim'in Misır't almasıyla Osmanlı Hanedani'na geçer.

Cumhuriyetin ilanından sonra gündeme gelen Halifeliğin kaldırılmast meselesi, 3 Mart 1924'te gerçekleşir. Varlığı iki başlılık yaratan, Mustafa Kemal'in ilerde yapmayı düşündüğ̈̈ inkılaplar karşısında bir engel olarak görülen halifelik kurumu kaldırılmış ve ertesi gün başta Halife olmak üzere 234 Osmanlı hanedanı üyesi yurt dışına çıkarılmıştır.

Anahtar Kelimeler : Halife, halifelik, Mustafa Kemal, Osmanlı hanedanı

\section{ABSTRACT}

The caliphate, which emerged following the death of the prophet Muhammed, passed to Ebubekir, Ömer, Osman, and Ali respectively, who all belonged to the Kureysh tribe. The caliphate which then passed to the Emevis and the Abbasites, ended when the Mongol ruler Kubilay murdered the last caliph. The caliphate, which was claimed in some parts of the world, passed to the Ottoman dynasty when Yavuz Selim conquered Egypt.

The issue of the abolition of the caliphate that became a matter of debate after the proclamation of the republic, happened on 3 March 1924. The institution of the caliphate, the presence of which caused a state of a double leadership and which was regarded as an obstacle to the revolutions which Mustafe Kemal intended to

\footnotetext{
*Ankara Üniversitesi Türk İnkılap Tarihi Enstitüsü öğretim üyesi
} 
realize in the future, was abolished and the next day the caliph and 234 members of Ottoman dynasty were expelled out of the country.

Key words : Caliph, caliphate, Mustafa Kemal, Ottoman dynasty

Atatürk devrimlerinin en önemlilerinden biri 3 Mart 1924 tarihinde Halifeliğin kaldırılmasıdır. Çünkü bu devrim yalnız Türkleri değil bütün İslam dünyasını ilgilendirmektedir.

İslam tarihinde Halifelik, Peygamber' in ölümü üzerine ortaya çıkan bir kurumdur. Hilafet, İslam içinde en uzun kalmış kurumlardan biridir. Uzun bir süre İslam toplumunun liderliği iddiasıyla şekillenen kurumunun tarihsel gelişim süreci İslam tarihsel serüveniyle iç içedir.

Hilafet Arapça half sözcüğünden gelmekte, birinin ardından gelen, yerine geçen anlamına gelmektedir. Bunun dışında tarikatların örgütlenmesinde şeyhin belirli yetkiler taşıyan temsilcisine halife denilmiştir. Osmanlı Devletinde merkez örgütlerinde uzman düzeyine ulaşmış görevlilere de halife denilmiştir. Halife kelimesi Tükçede kalfa olmuştur. Arapça Halife, Peygamberin yerine kaim olmak üzere İslam camiasının en yüksek reisinin unvanıdır. Halife İslam dininin esaslarına göre hem baş imam, hem de devlet başkanıdır. İki iktidarı birden temsil etmektedir.

Peygamber'in 8 Haziran 632 tarihinde vefatından sonra onun yerine kimin geçeceği sorun olmuştur. O ölümünden sonra yerine kimin geçeceği hakkında hiçbir öğütte veya vasiyette bulunmamıştır. Halifelik benden sonra otuz yıldır, ondan sonrası ısırıcı sultanlık olur demiştir. Kur' anda Halife ve İmam tabirleri geçmekte ise de, bu ayetler cemiyetin düzenini sağlamak, anarşiyi önlemek ve adaletle hükmetmek gibi bir görev anlamına gelmekteydi. ${ }^{1}$ Halifelik için iki aday bulunuyordu. Ebubekir ve peygamberin yeğeni ve damadı olan Ali. Ali aileden olduğunu belirterek başa geçmenin kendi hakkı olduğunu öne sürerken Ebubekir devlet işlerini yürütecek ve düşmanlara karşı savaşacak bir başkanın gerektiğini belirtmişti. Sonuçta Ebubekir seçilmiş kendisine Halife sanı verilmişti. Ebubekir'den sonra Ömer, Osman ve Ali Halife seçilmişlerdi. Dört Halife döneminde (632-658) halifelerin başlıca görev ve sorumlulukları dini korumak, toplum içinde kavga ve husumeti ortadan kaldırmak, toplumsal düzeni sağlamak, cezaları uygulamak, din düşmanlarına karşı savaşmak, halktan kanuni vergileri toplamak, hazineden ihtiyaç içinde olanlara yardım yapmak, memurların tayini ve denetimi olarak belirlenmişti. ${ }^{2}$ Bununla birlikte halifelerin sınırsız bir iktidar ve otorite sahibi oldukları iddia edilemez. İlk

' Şinasi Altundağ, “ Hilafet ve Hilafetin İlgası” Atatürk Önderliğinde Kültür Devrimi, Ankara, 1972, s.41.

${ }^{2}$ Namık Sinan Turan, Hilafetin Tarihsel Gelişimi ve Kaldırılması, İstanbul, 2004, s. 30. 
dört halifeden üçünün öldürülmesi. Bu makamın oraya seçilen kişilerin kutsal olarak tanınmadıklarını kanıtlamaktadır.

Ali'nin Emeviler soyundan Muaviye tarafından öldürtülüp Muaviye'nin halifeliği zorla ele geçirmesiyle hilafet Emevilere geçer. Bundan sonra halifelik farklı bir şekle dönüşmüş, verasete dayanan bir sistem olmuştur. Dört Halife ve Emeviler döneminde (658-750) Halifelik Kureyşlerdedir. Emeviler dönemi Arapların kendilerini bir ulus olarak tanımlamak istedikleri bir dönem olduğundan din ikinci plânda kalmıştır. Bu dönemde İslamiyeti yaymak için fetihler yapılmış, İspanya bu dönemde fethedilmiştir.

Abbasiler döneminde (750-1258) Halifelik merkezi Bağdat olmuştur. Bu dönemde fetihler yapılmış, Harun Reşit ve oğulları Memun ve Mutasım zamanında ilim gelişmeleri desteklenmiştir. Ancak Halifeler zamanla halktan koparak saraylara çekildiler. Abbasilerin Şiilere ve Emevi ailesinden olanlara karşı güttükleri dışlayıcı siyaset nedeniyle, İslam ülkelerinde Halife sanını taşıyan hükümdarın sayısı üçe çıkmıştır. Önce Mısır'da Şii Fatımi Halifeliği kurulmuş (909-1171) ardından İspanya'da Abdurrahman III. (929) Halifeliğini ilan etmiştir.

Türkler Selçuklu devletinin kuruluş döneminde Halifeliği ele geçirmişler fakat bu sanı almak gereğini duymamışlardır. 1058 yılında Bağdat'a giren Tuğrul Bey, Halifeyi makamında bırakmış ve yalnız Sultan-1 İslam sanını almıştı. ${ }^{3}$

Abbasi soyundan gelen bu halifelik, 1258 'de İlhanlı hükümdarı Cengiz Han'ın torunu Hülagu'nun Bağdat'a girmesiyle son buldu. Halife Mutasım öldürüldü. Mutasım'ın amcası El Mustansır Billah, katledilen sülalenin kurtulabilen tek üyesi olarak 1261 'de Misır'da Kölemenlere sığındı. ${ }^{4}$ Kölemenlerin hiçbir devlet başkanı yetkisi tanımaksızın onayladıkları bu halifeyi 17 halife izlemiştir. Bu dönemde İslam dünyasının Halifeliğin varlığından haberi olmamıştır. Bazı Türk devlet başkanları pozisyonlarını kuvvetlendirmek için halife unvanı kullandıkları görülmüştür. ${ }^{5}$

Yavuz Selim 1517'de Mısır'ı ele geçirince orada Halife III. El Mütevekkil Allah'la karşılaşır. Halife Mütevekkil birçok bilgin ve sanatçı ile birlikte İstanbul'a gönderilir. Padişahın İstanbul'a dönüşünden sonra Halife' nin uygunsuz hareketleri görülmüş ve Yedikule'ye hapsedilmiştir. Kanuni' nin tahta çıkmasıyla affedilerek Kahire'ye dönmesine izin verilmiş ve orada ölmüştür. Yavuz Selim'in halifeliği devraldığı yönünde yanlış bir kanı yaygınlaşmıştır. Ancak Selim'in, oğlu Kanuni ile yazışmalarında Halifeliği üzerine aldığına dair hiçbir şey yazmamıştır. ${ }^{6}$ O döneme ilişkin Osmanlı ve

\footnotetext{
${ }^{3}$ Şerafettin Turan, Türk Devrim Tarihi, 3. Kitap (Birinci Bölüm), İstanbul, 1995, s.47.

${ }^{4}$ Seçil Akgün, Halifeliğın Kaldırılması ve Laiklik (1924-1928), Ankara, Olgaç Matbaası, s.14.

${ }^{5}$ İslam Ansiklopedisi, "Halifelik" Maddesi, s.153.

${ }^{6}$ Munşa'at el-Selatin: Yayınlayan: Feridun Ahmet, İstanbul, 1859. C.I., s.376-379.
} 
Arap belgelerinin hiçbirinde, o yıllarda yazılmış kitaplarda böyle bir devir işlemini gösteren kayıt yoktur. Y Yavuz Selim'den önce bazı Osmanlı padişahları halife unvanını kullanmışlardı. Yavuz Selim, halife unvanını değil eski kutsal Hilafet emanetlerini almış ve Mısır sultanlarının "hadimü'l haremeyni'ş-şerifeyn" (kutsal Mekke ve Medine'ye hizmet eden) unvanını kullanmıştır. Bu söylenti 1774 Küçük Kaynarca Antlaşması'ndan sonra ortaya atılmıştır.

Osmanlılar, kaybettikleri ülkeler üzerinde padişahın sözde manevi gerçekte dünyevi haklarını korumak için halife unvanından yararlanmayı ümit etmişlerdi. Kırım 1783 'de Rusya tarafından ilhak edilince, Osmanlı halifelik iddiaları da temelsiz kalacaktır. Fakat Osmanlı padişahları halife sanını kullanmaya devam etmişlerdir.

Osmanlı Devleti parçalanırken II. Abdülhamit İslam birliğinin kurulmasında halifeliği çok önemli bir araç olarak kullanmıştır. Bütün çalışmalara karşın, siyasal gelişmeler ve ulusçuluk akımının Müslüman ülkelerde de başlaması, kurtarıcı olarak görülen halifelik sanını etkisiz kılmıștır. ${ }^{8}$ İngiliz şairi Wilfrid Scawen Blunt, "ruhani hilafet" kavramını gündeme getirmiş ve düşüncelerini Mekke Şerifi ve Mısır Hidivi'ne anlatmıştır. Mekke Şerifi Hüseyin, İngiltere'nin kışkırtmasıyla 1916'da Osmanlı Devleti'nin cihat ilanına rağmen ayaklanmıştır. Suriye'de hilafetin Osmanlılardan alınarak bir Arap Halifeliği kurulması amacıyla bir dernek kurulmuştur.

Blunt'in görüşleri Jön Türkler'den Mizancı Murat ve Cemalettin Efgani tarafından geliştirilmiş ve bu İttihat ve Terakki üzerinde etkili olmuştur. İttihat ve Terakki yöneticileri kaybedilen topraklar üzerinde siyasi nüfuz kurmak amacıyla Cihat ilan etmiştir. Fakat bu çağrıya Türk Müslümanlarından başka uyan olmamıştı.

Halifenin manevi varlığı, imparatorluk içindeki toplulukların milliyetçilik cereyanlarının yayılmasını önleyememiş; Mondros Mütarekesi sonrasında imparatorluk topraklarını işgal eden İngiliz ve Fransız ordu birliklerinin içinde Müslüman askerlerinin de bulunması sakıncalı bulunmamıştır.

Padişah dini yetkilerini, manevi otoritesini, Anadolu'da düşmanla savaşan kahramanları, başta Mustafa Kemal Paşa olmak üzere ölüme mahkum etmekte bir sakınca görmedi. Bu yolla sonuç alamayınca TBMM ordularının karşısına düşman güçleri paralelinde savaşmak üzere Halife kuvvetleri çıkardı. Bunca kötü harekete araç edilmiş Halifelik, kimileri için

${ }^{7}$ Bkz., Faruk Sümer, "Yavuz Selim Halifeliği Devraldı mı ?" Tarih ve Düşünce, S. 4 (Şubat 2000), s. 20.; N. Ahmet Asrar, "Hilafetin Osmanlılara Geçişi Ille İlgili Rivayetler", Türk Dünyası Araştırmaları, S.22 (Şubat 1983), s.94.

${ }^{8}$ Şerafettin Turan, a.g.e., s.48.

${ }^{9}$ Bilal N. Şimşir, Doğu'nun Kahramanı Atatürk, İstanbul, 1999, s.109. 
hâlâ padişahın tanrısal gücünü niteleyen mukaddes bütün Müslümanların ortak kurumu idi ve vazgeçilemezdi. ${ }^{10}$

Saltanatla hilafetin ayrılacă̆ı gün yapılan tartışmalarda Mustafa Kemal halifelik kurumunun nasıl ortaya çıktığı ve ne gibi değişiklikler geçirdiğini anlatmıştı. " Saltanat kaldırılıp kimin halife olabileceği gündeme geldiğinde, aday olarak Padişah Vahidettin ve Veliaht Abdülmecit üzerinde durulmuștu. Mustafa Kemal Vahidettin'i, Kazım Karabekir ise Abdülmecit'I önermişti. ${ }^{12}$ Ancak Vahidettin 17 Kasım 1922'de Malaya zırhlısı ile kaçıp İngilizlere sığınınca yeni bir halife seçimi kaçınılmaz olmuştu. Ankara Hükümeti'nin Diyanetişleri Bakanı Mehmet Vehbi Efendi, Padişahlığı kaldırılmış olan Vahidettin'in yurt dışına kaçmış olmasından dolayı halifeliği de yitirdiğine, Halifelik Makamının boş kalmış olduğuna, yeni bir halifenin seçilmesi gerektiğine dair bir fetva çıkardı. 18 Kasım 1922'de B.M.M'de okunan önerge kabul edilmiş ve Vahidettin halifelikten düşürülmüştür. ${ }^{13}$ Malta'ya giden Vahidettin, Padişahlıktan ve Halifelikten umudunu kesmiş görünmüyordu. Fakat Hicaz Kralı Hüseyin'in daveti üzerine Hicaz'a giden Vahidettin umut kırıklı̆̆ına uğradı. Hicaz'dan ayrılıp Mısır, Ürdün veya Kıbrıs gibi Müslümanların yaşadığı bir yere gitmek istedi. Ancak İngilizler buna izin vermediler. Sonunda İtalya'nın San Remo şehrinde oturmasına müsaade edildi. Vahidettin üç yıl sonra San Remo' da ölecek ve Şam'a gömülecektir. ${ }^{14}$

Halifeliğin en güçlü adayı Abdülmecit idi. Mustafa Kemal onu kurtuluş hareketini güçlendireceği düşüncesiyle Ankara'ya çağırmış fakat o bir kardeş kavgasına neden olmamak için Anadolu'ya geçmemişti. Bir yıl sonra, II. İnönü zaferi kazanılınca oğlu Ömer Faruk Efendi kendi isteğiyle Anadolu'ya geçmek istemiş, Mustafa Kemal bir kargaşalık çıkmaması için onu İnebolu'dan İstanbul'a geri göndermişti. ${ }^{15}$

18 Kasım 1922 'de B.M.M' de yapılan seçimde 162 oy kullanılmış, Abdülmecit Efendi 148 oyla halife seçilmişti.. Oyların 2'si Abdülhamit'in oğullarından Abdürrahim'e, 3'ü de Abdülhamit'in büyük oğlu Selim'e verilmiş, 9 mebus da çekimser oy kullanmıştı. ${ }^{16}$ Yeni Halife İslam âlemine bir bildiri yayımlamıştı.

${ }^{10}$ Türk Parlamento Tarihi, TBMM- 2 Dönem, 1923 - 1927, . C. I., Ankara, 1993, s.279.

"Atatürk'ün Söylev ve Demeçleri (1919 - 1938), C.I., Ankara, Türk Tarih Kurumu Basımevi, 1961, s.269-280.

${ }^{12}$ Mustafa Kemal Atatürk, Nutuk, C.II, İstanbul, 1975, s.297- 309; Uğur Mumcu Kazım Karabekir Anlatıyor, Ankara, Tekin Yayınevi.1990, s.40-70.

${ }^{13}$ Naşit Hakkı Uluğ, Halifeliğin Sonu, İstanbul, 1975, 85 v.d.; Mustafa Kemal Atatürk, Nutuk, C.II., s.303.

${ }^{14}$ Bilal N. Şimşir, a.g.e., s.117-118.; Mahmut Goloğlu, Halifelik. Ne idi? Nasıl Alındt? Niçin Kaldırıldı? Ankara, Kalite Matbaası, 1973, s.36.; Naşit Hakkı Uluğ, a.g.e., s.99.

${ }^{15}$ Asım Gündüz, (Derleyen ve Yazan İhsan Ilgar), Hattralarım, İstanbul, 1971, s.42-43.

${ }^{16}$ Naşit Hakkı Uluğ, Halifeliğin Sonu, İstanbul, 1975, s.97. 
Mustafa Kemal Halifeye, aynı gün Refet Bey aracılığıyla uyması gereken kuralları bildirmişti. Abdülmecit, yalnız Halife-i Müslimin sanını kullanacak, buna başka şeyler eklemeyecekti. İslam dünyasına yayınlayacağı bildiride; TBMM'nin ve hükümetinin Türkiye halkı ve bütün İslam âlemi için en uygun bir sistem olduğunu belirtecekti. Mustafa Kemal ayrıca halifenin yetki sınırını belirleyen bir uyarıda da bulunmuştu. ${ }^{17}$

Yeni Halifenin seçim işlemi tamamlandıktan sonra Meclis Başkanlık Divanı Halifenin göreve başlaması, kutlama ve kutsal emanetleri ${ }^{18}$ teslim töreni için milletvekillerinden oluşan bir heyet göndermişti. 19 kişiden oluşan bu heyet Halifeye 24 Kasım 1922'de bu emanetleri bir törenle teslim etti. $^{19}$

Abdülmecit, davranışlarının sınırlandırılmasını kabul etmemiş, Refet Bele' ye Halife-i Müslimin sanına ek olarak Hadimu'l Haremeyn sanını da kullanmak istediğini, Cuma Selamlıkları'nda hil'at ve Fatih Mehmet'in kullandığı sarığa benzer bir sarık takmak istediği söylemişti. Ancak Mustafa Kemal verdiği yanıtta redingot giyebileceğini askeri üniformanın ise söz konusu olmayacağını belirtmişti. ${ }^{20}$

Mustafa Kemal, Cumhuriyetin ilanından sonra, Cumhuriyete gölge edebilecek, Cumhuriyetin ilanından memnun olmayanların siyasi ihtiraslarına alet olabilecek bir mahiyet göstermesi bakımından Halifeliği rejim için zararlı görmekte idi. O, " Kişisel saltanatın kaldırılmasından sonra, başka unvanla aynı nitelikte bir makamdan ibaret kalması gereken halifeliğin de kaldırıldığını kabul ediyor" bunun için uygun bir zaman ve fırsat bekliyordu. Türlü olaylar Mustafa Kemal'e bu düşüncesinde yanılmadığını gösterdi. ${ }^{21}$

Çok geçmeden Meclis içinde halifelik lehinde, Mustafa Kemal aleyhinde başlatılan kışkırtmalar, basınla yurt sathına yayılmaya başladı. Mustafa Kemal halkın düşünce ve eğilimlerini saptamak amacıyla, 14 Ocak 1923'te Batı Anadolu gezisine çıkmış ve halkın halifelik konusunda bilgi edinmek istediğini anlamıştı. Bu günlerde İskilipli Atıf Hoca ve Milletvekili Şükrü Hoca birer kitap yayımladılar. Atıf Hoca İslam Yolu adlı kitapta halifenin din işlerinin yanında dünya işlerine de bakması gerektiğini savunuyordu. Sükrü Hocanın Hilafeti İslamiye ve Büyük Millet Meclisi adlı kitabında "Halife Meclisin, Meclis Halifenindir" sloganı işleniyordu. Ona göre devlet başkanı olacak kişi Padişah ve Halife diye iki ayrı san yerine

${ }^{17}$ Mustafa Kemal Atatürk, Nutuk, C.III, Belgeler, İstanbul, 1973, B. 265, s.1251- 1252.

${ }^{18}$ Kutsal Emanetler Yavuz Selim Mısır'ı aldığında Mekke Şerifi tarafından kendisine gönderilmişti. Bunlar Yavuz'un başka yerlerden getirttiği eserlerle birlikte Topkapı Sarayında toplanmıştı. Bkz., Hilmi Aydın, Hırka-i Saadet Dairesi ve Mukaddes Emanetler, Istanbul, 2004.

${ }^{19}$ Türk Parlamento Tarihi, 1919 - 1923, C. 1., Ankara, 1994, s.286-287.

${ }^{20}$ Mustafa Kemal Atatürk, Nutuk, C.II, s.305.

${ }^{21}$ I slam Ansiklopedisi, "Atatürk” Maddesi, s.773. 
Halife diye anılmalıydı. ${ }^{22}$ Hoca Şükrü ve arkadaşları bu safsatayla, Millet Meclisi'ni Halife' nin danışma kurulu ve Halife' yi Meclis' in dolayısiyle devletin başkanı gibi göstermek ve kabul ettirmek istemişlerdi. ${ }^{23} \mathrm{Bu}$ yayınlardan güç alan Abdülmecit, zaman zaman hükümdar gibi davranmaya başlamıştı. Mustafa Kemal'e gönderdiği bir telgrafta bu büyük değişikliği "yenilenen hükümet biçimi" olarak nitelemişti. Padişah oğlu olduğunu vurgulamak için imzasını "Abdülmecit bin Abdülaziz Han diye atmıştı. Halife-i Müslimin sanı ile yetinmeyip buna Zıllullah’ı (Tanrını gölgesi) da ekleyerek hükümetin talimatı dışına çıkıyordu. Öte yandan Cuma Selamlıkları düzenliyor, İstanbul'daki yabancı devlet temsilciliklerine görevliler göndererek ilişki kurmaya çalışıyordu. $\mathrm{Bu}$ durum Ankara'daki geriye dönüş ve Halifelik yolundan sultanlığa gidiş korkusunu daha da arttırdı. Muğla mebusu Yunus Nadi (Abalı̆̆̆lu) Bey, Yenigün Gazetesinde çok sert ve suçlayıcı iki yazı yayımladı. Bu yazılar karşı tepkilere yol açtı. Konu Meclise getirildi. Karşı tepki çok sert oldu. Konu bir karara bağlanmadan sonuçlandı fakat Halifeliğin devam etmesi halinde bir geriye dönüş davranışının olabileceği kuşkusu da köklü bir kanıya döndü. ${ }^{24}$

Mustafa Kemal yurt gezilerinde halifelikle ilgili sorulara, ulusça kurulan yeni devletin kaderine, işlerine, bağımsızlığına sanı ne olursa olsun hiç kimsenin karışmasına izin verilmeyeceğini, Halifeye yeni yetkiler tanıyıp onu tekrar bir Padişah durumuna getirmek istemenin ulusu yok etmeye çalışmak olduğunu anlatmıştı. Halifelik lehinde yayımlanan bu kitaplara yanıt olmak üzere Hilafet ve Hakimiyet-i Milliye adlı bir kitap yayımlanmıştı.

Cumhuriyet ilan edilirken TBMM'i halifelikle ilgili bir karar almamıştı. Cumhuriyetin ilanını ve Mustafa Kemal'in Cumhurbaşkanlığına seçilişini ilk kutlayanlardan biri Halife Abdülmecit Efendi olmuştu. ${ }^{25}$ Fakat, Cumhuriyetin ilanı ile beraber, Halifeliğin kaldırılacağı Halifenin istifa ettiği yolunda kışkırtıcı haberler yayılmaya başladı. Rauf Bey, İstanbul basınına Cumhuriyetin ilan yöntemini ve alınan son kararları eleștiren bir demeç verdi. Rauf ve Adnan (Adıvar) Beyler ile birlikte Refet Paşa, Halife' yi ziyaret ettiler. Rauf Bey bir plânın içindeydi. Bu plânı gerçekleştirmek için Ankara'da da parti ve meclis içinde faaliyete girişti. ${ }^{26}$

Hükümetin Trakya ve İstanbul'daki temsilcisi Refet Paşa, Halife' ye yaklaşmış ve Konya isimli atını Halife' ye hediye ederken "Bu hayvanın Halife Hazretleri tarafından beğenilmesini Tanrının bir lütfu sayıyorum" demişti. ${ }^{27}$

\footnotetext{
${ }^{22}$ Şerafettin Turan, a.g.e., s.53.

${ }^{23}$ Mustafa Kemal Atatürk, Nutuk, C.II., s.314.

${ }^{24}$ Mahmut Goloğlu, a.g.e., s.41.

${ }^{25}$ Türk Parlamento Tarihi, II. Dönem, C.I., s. 296 ;

${ }^{26}$ M. Kâmran Ardakoç, Hilafet Meselesi, İstanbul, Petek Yayınları, 1955, s.27

${ }^{27}$ Mustafa Kemal Atatürk, Nutuk, C.II, s.314-315.
} 
İstanbul'daki gelişmeler bir geriye dönüş kuşkusu doğurmuş, İstanbul' daki olaylara elkoymak ve basının tutumu ile ilgilenmek üzere bir İstiklal Mahkemesinin kurulması kararlaştırılmıştı. Buna rağmen İstanbul basınındaki kışkırtıcı yayımlar durmamıştı. Yurt dışında da önemli gelişmeler oluyordu. Londra'daki Seyit Emir Ali başkanlığındaki İslam Cemiyeti Sekreteri Sait S. Muhammedi, Dahiliye Vekili Fethi Bey'e gönderdiği 2 Eylül 1923 tarihli mektubunda hilafetin korunması gerektiğini bildirmişti. Hindistan'daki İsmailiye mezhebinin lideri olan Ağa Han ile Hintli Emir Ali de Başbakan İsmet Paşa'ya 5 Aralık 1923 tarihinde bir mektup göndermişlerdi. Bu mektup Başbakanın eline geçmeden Tanin, ikdam ve Tevhidi Efkar gazetelerinde yayımlanmıştı. ${ }^{28}$ Mektubun basında yayımlanmasından sonra Başbakan İsmet Paşa, TBMM'de yapılan gizli görüşmede konunun ele alınmasını istedi. Mektubu yayımlayan gazeteciler tutuklandılar fakat mahkeme sonunda beraat ettiler.

1924 Yılı başında Halifeliğin kaldırılmasını hızlandıran gelişmeler olmuştu. Halife, İstanbul'a gelen hükümet üyelerinin kendisini ziyaret etmemelerinden üzüntü duyduğunu belirtmiş ve 'Halifelik Hazinesi' nin gücünü aşan ve görevi dışında kalan harcamalar için devlet bütçesinden yardım yapılmasını istemişti. Başbakan durumu Mustafa Kemal'e iletmiş . Mustafa Kemal, devlette Halifelik Hazinesi adıyla ayrı bir hazinenin olamayacağını belirtmiș, Halifenin ne olduğunu bilmesini ve bununla yetinmesini, hükümetin bunu sağlayacak önlemler almasını dilemişti. ${ }^{29}$

Mustafa Kemal'i Halifeliğin kaldırılması için zorlayan en kuvvetli etken, Halife var oldukça Türkiye'de yapmayı düşündüğü toplumsal ve laik devrimlere imkan olmayacağı düşüncesiydi. Hilafet sorunu aslında bir rejim sorunuydu. Mustafa Kemal, Hilafet sorununu tamamen ortadan kaldırmak için bir dizi girişimde bulundu. İstanbul basının, Darülfünunda görevli aydınların, Milli Mücadele'nin önder kadrosunu oluşturan yakın arkadaşlarının ve diğer ordu kumandanlarının kendi düşüncesi doğrultusunda tutum almalarını sağlamaya çalıştı. ${ }^{30} \mathrm{Bu}$ konuda kesin karar almak zamanının geldiğini anlayınca 15-20 Şubat 1924'te yapılacak Harp Oyunları nedeniyle Ordu ve Kolordu Komutanlarını İzmir'de topladı. Bu toplantıya Başbakan İsmet Paşa, Savunma Bakanı Kâzım Özalp Paşa ve Genelkurmay Başkanı Fevzi Çakmak da katılmıştı. Toplantıda, Hilafet ile, Şer'iye ve Evkaf Bakanlığının kaldırılması ve öğretim kurumlarının birleştirilmesi karar altına alınd.$^{31}$

${ }^{28}$ Mektuplar için bkz., Neslihan Erözbek - Fethi Kayalı, (Haz.,) " Bir Mektup ve Hilafet Meselesinin Gündeme Gelmesi”, Belgelerle Türk Tarihi Dergisi, S. 43 (Eylül 1988), s.46-49.; Türk Parlamento Tarihi, II. Dönem, C.I, s.383.

${ }^{29}$ Mustafa Kemal Atatürk, Nutuk, C. II, s.478-480; Naşit Hakkı Uluğ, a.g.e., s.153-154.

${ }^{30}$ Türkiye Tarihi, (Haz., Sina Akşin v.d.) ,C.4, İstanbul, 2002, s. 136.

${ }^{31}$ Mustafa Kemal Atatürk, Nutuk, C. II., s.480. 
Mustafa Kemal 24 Şubatta Ankara'ya döndü. 1 Martta Meclisin yeni dönemini açarken yaptığı konuşmada hükümetin faaliyetlerini ana hatları ile anlattı. 2 Martta Halk Fırkası parlamento grubu üç yasayı onaylamak için toplandı. Ertesi gün üç önerge meclise sunuldu. Tartışmalar sonunda 3 Mart 1924'te, 429 sayılı Kanunla Siirt mebusu Halil Hulki ve elli arkadaşının önergesi kabul edilerek Şer'iye, Evkaf ve Erkan-1 Harbiye-i Umumiye Bakanlıkları kaldırıldı. 430 sayılı Kanunla, Manisa mebusu Vasıf Bey ve elli arkadaşının önergesi kabul edilerek eğitim ve öğretimin birleştirilmesi Kanunu kabul edildi. 431 sayılı Kanunla Siirt Mebusu Şeyh Saffet Efendi ve 53 arkadaşının önergesi kabul edilerek, Halifeliğin kaldırılmasına ve Osmanlı Hanedanının Türkiye dışına çıkarılmasına karar verildi. ${ }^{32}$ Böylece, Osmanlı Devleti' in son kalıntısı ve Cumhuriyet yönetimi için tehlike haline gelmiş olan halifelik tarihe karıştı. Kaldırılan bakanlıklar yerine, Başbakanlığa bağlı Diyanet işleri Başkanlığı ile Genelkurmay Başkanlığı kuruldu.

431 sayılı yasa, Abdülmecit ile Osmanoğulları ailesinin bütün erkekleri, kadınları, damatları ve o kadınlardan doğan bütün çocukların Türk vatandaşlığından çıkarılmalarını ve Türkiye topraklarında oturmamaları hükmünü içeriyordu. Padişah ve ailesi hemen, diğer hanedan üyeleri ise on gün içinde bir daha dönmemek üzere yurtdışına çıkarılacaklardı. ${ }^{33}$ Yol giderleri için, servetlerine göre hükümetçe saptanacak paralar ödenecekti. Padişahlık yapmış olanların malları, saray ve köşkleri milletin malı sayılacaktı. Diğerlerinin taşınmaz mallarını bir yıl içinde elden çıkartmaları, aksi halde hükümetin bu malları satarak onlara göndermesi öngörülmüştü. ${ }^{34}$

Hükümet 2 Mart 1924'te bir komisyon kurarak saraylarda önlem alınmasını, dairelerin mühürlenmesini ve bu husustaki sorumluluğun Vilayete ait olduğunu kararlaştırmışt. ${ }^{35}$

Ayrıca, kafilenin sevk masrafı için 90.000 lira da tahsis edilmişti. Sarayların muhafazası için de bu paradan harcama yapılacaktı. ${ }^{36}$

Yasa onaylanır onaylanmaz, İstanbul Valisi Haydar Bey ile Emniyet Müdürü Sadettin Bey Dolmabahçe Sarayına giderek Abdülmecit'e derhal yola çıkmak için hazırlanmasını söylediler. Öfkeye kapılan Abdülmecit valiyi kovdu. Emniyet müdürü gerekirse kendini zor kullanarak götürmek için emir aldığını bildirdi. Saray sarılmış ve telefon hatları kesilmiş olduğundan Abdülmecit boyun eğmek zorunda kaldı. ${ }^{37}$ Kutsal Emanetleri

${ }^{32}$ Naşit Hakkı Uluğ, a.g.e., s.158-161.;

${ }^{33} 16$ Haziran 1952'de hanedanın kadın üyelerine, 15 Mayıs 1974 tarihinde çıkarılan bir kanunla da erkek üyelerine Türkiye'ye dönme izni verilmiştir. Bkz., Murat Bardakçı, Son Osmanlılar, İstanbul, 1991, Ek. VI, s.191-192.

${ }^{34}$ Türk Parlamento Tarihi, II. Dönem , C.I, s.348-351.;

${ }^{35}$ Emniyet Genel Müdürlüğ̈̈ Arşivi, ( E.G.M.A.), Ds. $1311 / 1$ - 2, B. 591.

${ }^{36}$ E.G.M.A., Ds. $1311 / 1-2$, B. 607.

${ }^{37}$ Kamran Ardakoç, a.g.e., s.53. 
yanında götürmek isteyen Abdülmecit Efendi'ye vali, bunların Halifenin kişisel eşyası olmayıp Türk ulusuna geçmiş olduğunu bildirdi. Abdülmecit ve sultanların yanlarında saraya ait kıymetli eşya ve mücevher götüremeyecekleri, ancak kendilerine ait mücevher ve kürkleri götürebilecekleri kararlaştırılmıştı.

İsviçre'ye gönderilmesine karar verilen Abdülmecit hemen ertesi günü 4 Mart sabahı oğlu Ömer Faruk, kızı Dürrüşehvar, kadınefendiler, Mabeyncisi Hüseyin Nakıp Turan Bey, doktoru Selahattin Bey, özel katibi Keramet Nigar'la birlikte yolculuk hazırlıklarına başladılar ${ }^{38}$ Abdülmecit'in sevki için Maliye Bakanlığı 10.000 lira tahsis etmişti. ${ }^{39}$ Abdülmecit ile birlikte hanedana üyesi ve hizmetlilerden oluşan 234 kişi yurt dişına çıkartılmıştır. ${ }^{40}$

Abdülmecit ve ailesi Çatalca tren istasyonunda uzun süre bekledikten sonra Simplon Ekspresiyle yola çıkar. Abdülmecit ve ailesine yol parası, isteği üzerine İngiliz lirası olarak ödenmiştir. Abdülmecit'e 15.000 lira (1700 İngiliz Lirası), diğer şehzade ve sultanların her birine 1000 lira ödenecekti ${ }^{41}$ Hükümet Bern'e kadar seyahat masraflarını karşılayacaktı. Maliye bakanlığının sevk için tahsis ettiği 140.000 Liranın, 139.898.075. Lirası harcanmıştı. ${ }^{42}$

Abdülmecit bir basın bildirisi yayınlayıp ulusun kararına boyu eğdiğini ve bundan sonra güzel sanatlarla uğraşacağını açıklar. Fakat tren Bulgaristan sınırını geçer geçmez bir bildiri daha yayınlayarak, makamından alınma kararını geçersiz saydığını belirtir. Ona göre yalnız Türklerin değil, bütün Müslümanların dinsel ve tarihsel kurumu olan halifelik tek yanlı bir kararla kaldırılamazdı. Abdülmecit ayrıca Halifeliğin yeniden canlanması için bir Din Şurası toplanması diler ve bütün Müslümanlardan yardım beklediğini bildirir. ${ }^{43}$

Ankara'nın uyarıları üzerine İsviçre yönetimi Abdülmecit'e bu tür faaliyetlerin istenmediğini bildirmiş, $\mathrm{O}$ da bir şura toplamaktan vazgeçmişti.

Abdülmecit Müslüman ülkelerden ve kuruluşlardan parasal yardım ve destek istemek için sekreterini Paris'e, sonra Londra'ya göndermiş fakat umduğunu elde dememişti. İsviçre'de fazla kalamayan Abdülmecit Nice' e taşındı. 1944 Ağustosunda Paris'te öldü ve Medine'de gömüldü. ${ }^{44}$ s.8.

${ }^{38}$ S. Keramet Nigar, Halife İkinci Abdülmecit, İstanbul, Tan Gazetesi Matbaası, 1964,

${ }^{39}$ E.G.M.A., Ds. $1311 / 1$ - 2, B.590.

${ }^{40}$ Emniyeti Umumiye Sicil Müdürlüğü ülke dışına çıkartılan 234 hanedan üyesi ve hizmetliler için 61 sayfalık bir albüm hazırlamıştır. Liste için bkz. Ek I. E.G.M.A., Ds. 1311/ 1-2, B. $1 / \mathrm{A}-1,1 / \mathrm{E}-3$.

${ }^{41}$ Seçil Akgün, a.g.e., s.200.

${ }^{42}$ E.G.M.A., Ds. $1311 / 1-2$, B. $14 / 330$.

${ }^{43}$ S. Keramet Nigar, a.g.e., s. 13.

${ }^{44}$ O Gazi Aşiroğlu, Son Halife Abdülmecit, İstanbul, 1992, s.130-134.; Seçil Akgün, a.g.e., s.214 . 


\section{EK I}

Yurt Dışına Çıkarılan Hanedan Üyeleri ve Hizmetliler

1. Sakat Halife Abdülmecit i. Abdülaziz

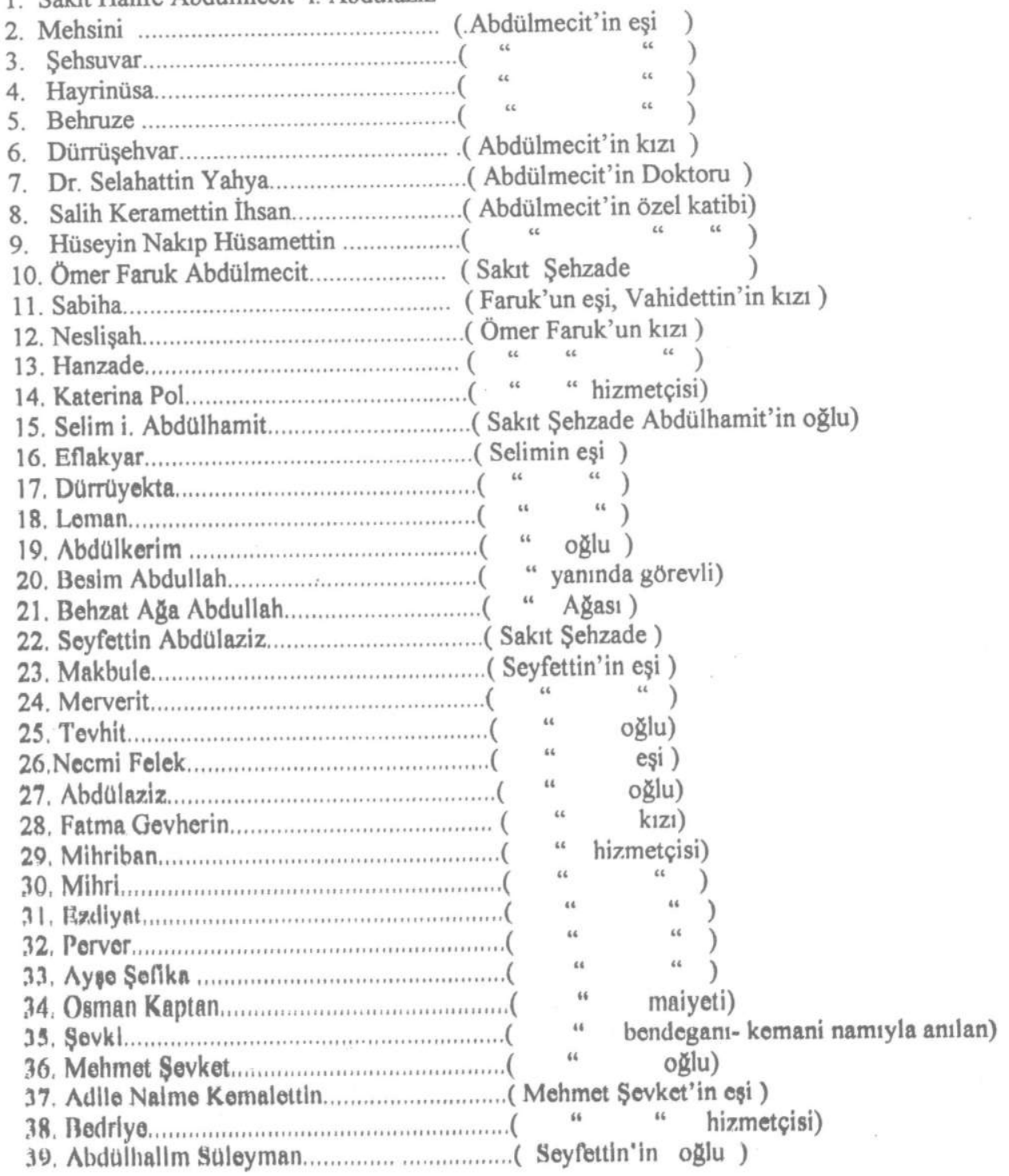


40. Saniye................................................... (Abdülhalim'in eşi

41. Semra.

(Abdülhalim'in kızı)

42. Habibe

(" hizmetçisi)

43. Ahmet Nihat

( Selahattin'in oğlu )

44. Safiru

(Ahmet Nihat'ın eși )

45. Nevrestan.

46. Ali Vasip

47. Aziz.....

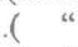

48. M. Ziyaettin

“ oğlu )

49. Perizat

( "

“ kayınbiraderi )

50. Nazım.

( M. Reşat' in oğlu )

51. Fevzi

( M. Ziyarttin'in eşi )

52. Rukiye

53. Hayriye.

54. Lütfiye.

55. Mihrimah.

56. Mihrişah.

57. Vedat.

58. Pesent

59.. Ayşe Neşement

60. Emine Sedat.

61. Ayşe.

62. Fatma

63. Ömer Hilmi

64. Mihrengiz

65. Mukbil

66. Mahmut Namik

67. Ayșe.

68. Șerafettin

69. Sukriyo Y. Izettin.

70.. Gulmisal.

71. Mislibehar.

72. M. N. Nizamettin.

73. Mihriban Mihrişah

74. Zenci Ferhat A gra

75. Fatma Dilsaz.

76. Kafestan

77. Aynı Melek

78. Seza

79. Ahmet Nuri

80. Fahriye

81. Raşel.

82. Abdülkadir

83. Hatice Macide

84. Meziyet.

85. Orhan.

86. Ertuğrul

87. Alaettin

88. Bidar.

89. Sahver.

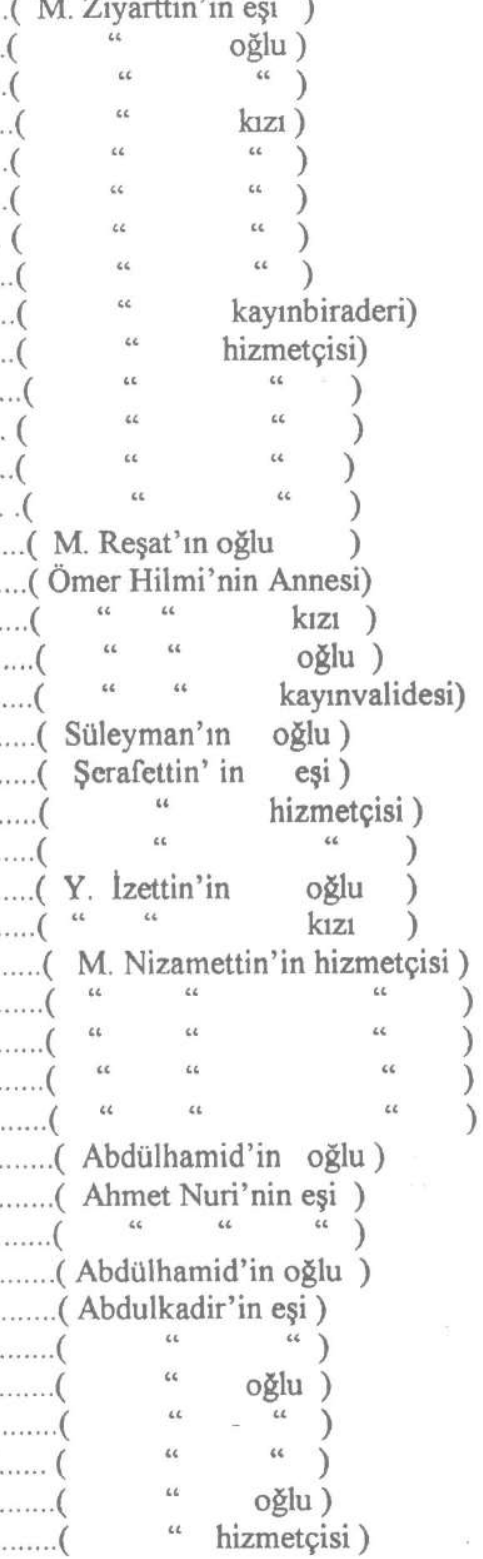




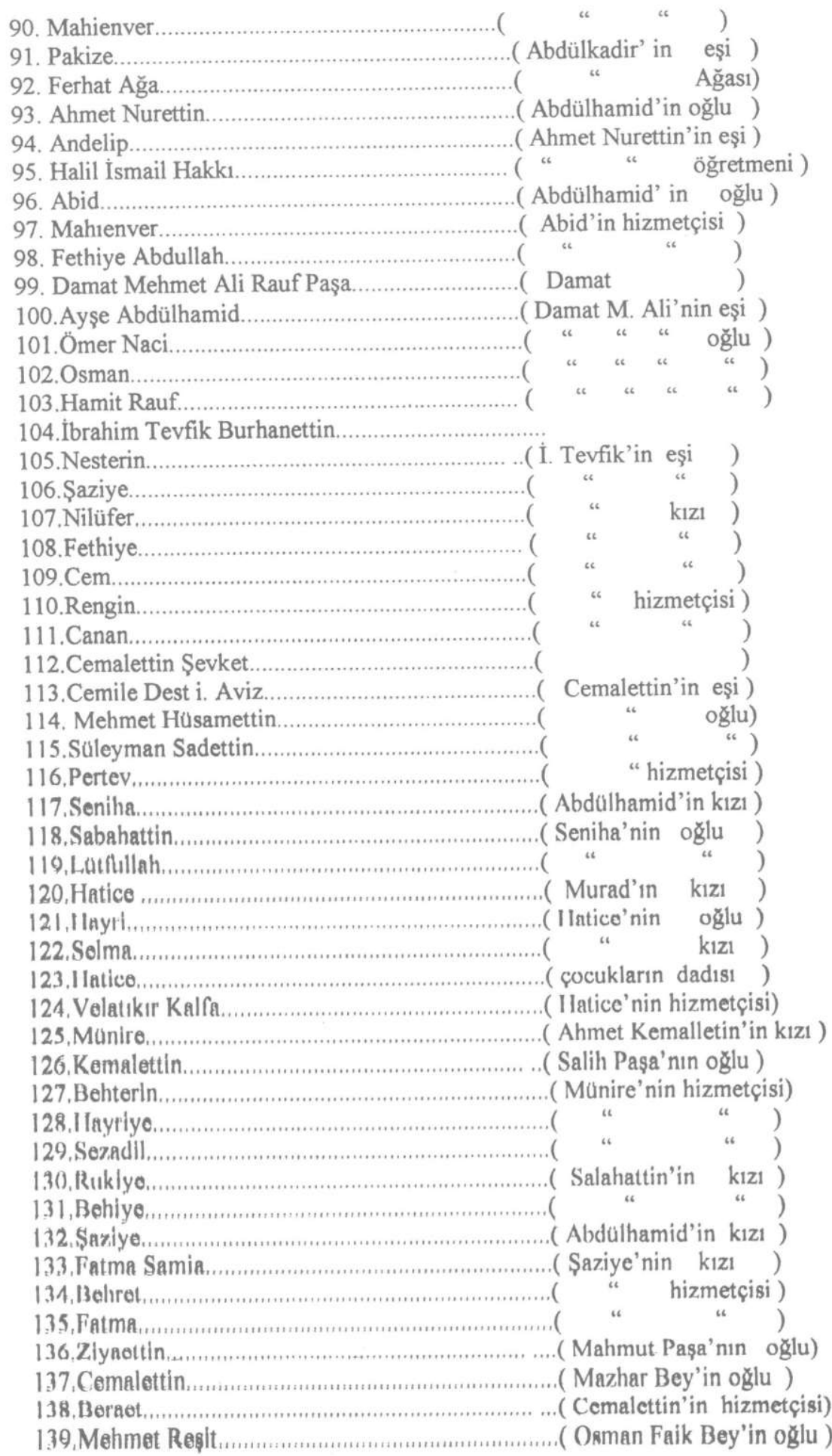




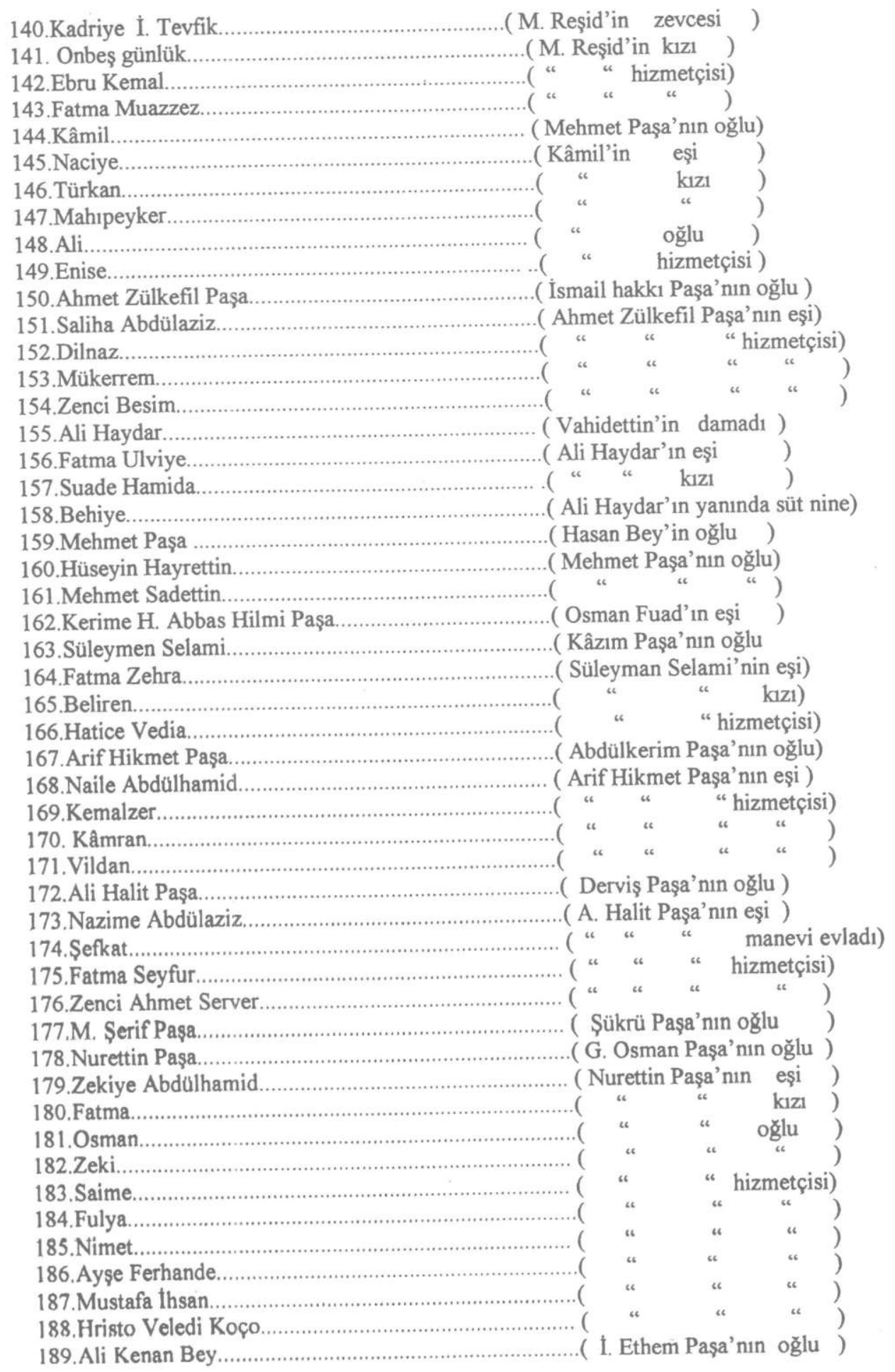




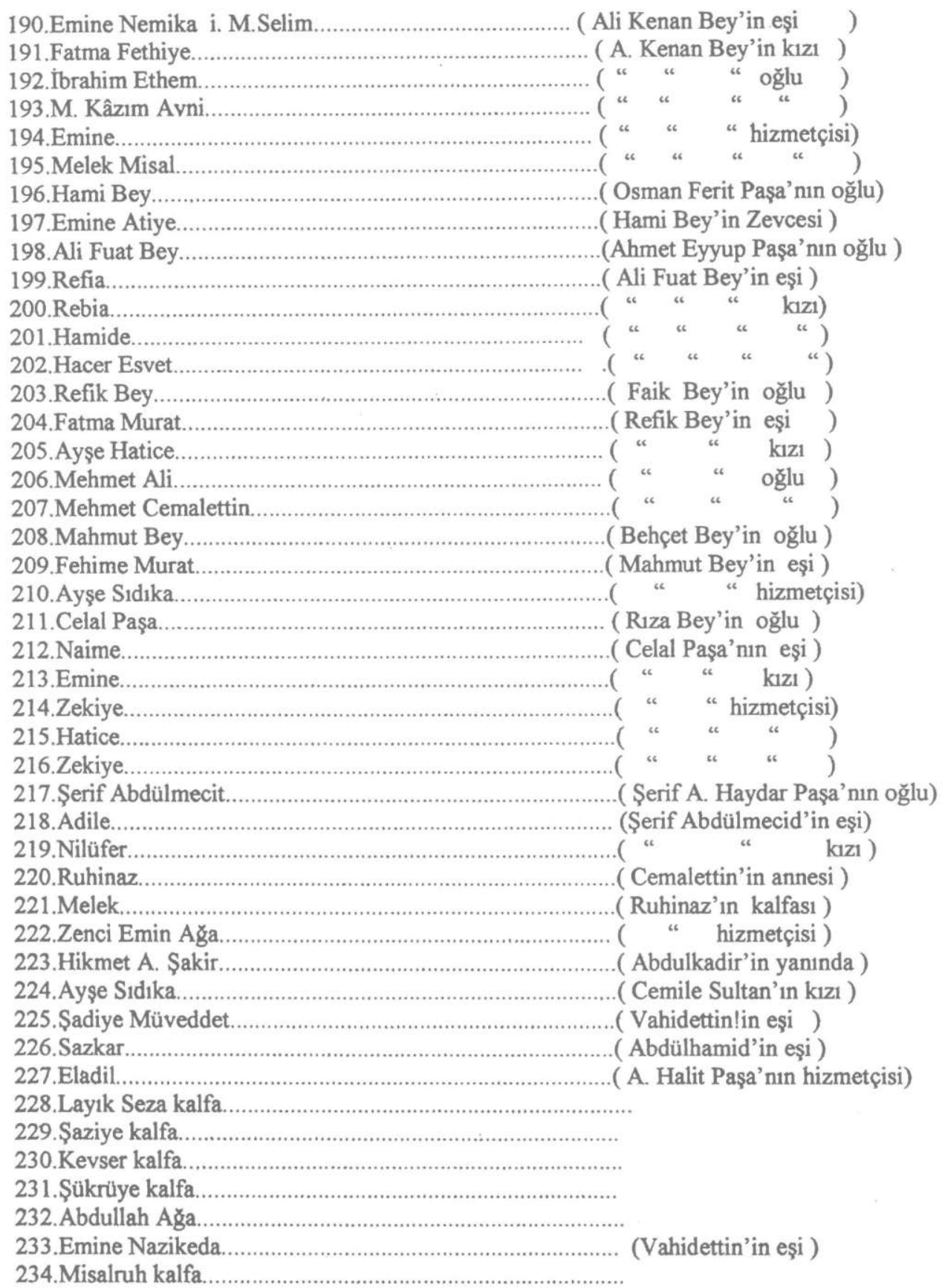

